\title{
FUEL CELL: FEASIBILITY ANALYSIS OF ITS APPLICATION IN AUTOMOBILES
}

\author{
R. M. Gontijo, \\ L. M. Silva, \\ and A. R. Pereira \\ Pontifícia Universidade Católica de MG \\ Departamento de Engenharia Mecânica \\ Instituto Politécnico da PUC Minas \\ Bairro Coração Eucarístico \\ Av. Dom José Gaspar, 500, \\ Belo Horizonte, MG, Brasil \\ rodmenegontijo@gmail.com \\ Received: April 14, 2018 \\ Revised: May 11, 2018 \\ Accepted: May 31, 2018 \\ ABSTRACT
The need to reduce the emission of harmful gases into human life, together \\ with the dependence on oil as a primary source of fuel for internal \\ combustion engines (ICE), are part of the current global scenario. This \\ scenario opens space for fuel cells (FC), technology that generates \\ electricity as the main product of oxide-reduction reactions between \\ Hydrogen and Oxygen. An efficient and clean alternative that appears as a \\ possibility for the substitution of ICE. The present article proposes a model \\ of FC and compares it technically with a conventional ICE, in order to \\ prove the efficiency, performance and environmental impact feasibility of \\ the use of this technology in commercial vehicles.
}

\section{NOMENCLATURE}

$\begin{array}{ll}\text { AC } & \text { Alternating Current } \\ \text { ADVISOR } & \text { Advanced Vehicle Simulator } \\ \text { AFC } & \text { Alkaline Fuel Cell } \\ \text { BEN } & \text { Balanço Energético Nacional } \\ \text { BEV } & \text { Battery Electric Vehicle } \\ \text { BNDES } & \begin{array}{l}\text { Banco Nacional de Desenvolvimento } \\ \text { Econômico e Social }\end{array} \\ \text { BOC } & \text { Bureau of Census } \\ \text { CaC } & \text { Célula a Combustível } \\ \text { CL } & \text { Catalyst Layer } \\ \text { DC } & \text { Direct Current } \\ \text { DDP } & \text { Diferença de Potencial } \\ \text { EV } & \text { Electric Vehicles } \\ \text { FC } & \text { Fuel Cell } \\ \text { FCEV } & \text { Fuel Cell Electric Vehicle } \\ \text { GDL } & \text { Gas Diffusion Layer } \\ \text { HC } & \text { Hidrocarbonetos } \\ \text { HEV } & \text { Hybrid Electric Vehicle } \\ \text { ICE } & \text { Internal Combustion Engine } \\ \text { IPEN } & \text { Instituto de Pesquisas Energéticas e } \\ & \quad \text { Nucleares } \\ \text { MCFC } & \text { Molten Carbonate Fuel Cell } \\ \text { MCI } & \text { Motor de Combustão Interna } \\ \text { MME } & \text { Ministério de Minas e Energia } \\ \text { NASA } & \text { National Aeronautics and Space } \\ & \text { Administration } \\ \text { OECD } & \text { Organização para a Cooperação e } \\ & \text { Desenvolvimento Econômico } \\ \text { PAFC } & \text { Phosphoric Acid Fuel Cell } \\ \text { PCI } & \text { Poder Calorífico Inferior } \\ \text { PEMFC } & \text { Proton Exchange Membrane Fuel Cell } \\ \text { REEV } & \text { Range Extended Electric Vehicle } \\ & \text { Pand }\end{array}$

\author{
SI Sistema Internacional \\ SOFC Solid Oxide Fuel Cell \\ U.S. EPA United States Environmental Protection \\ Agency \\ UNCTAD Conferência das Nações Unidas sobre \\ Comércio e Desenvolvimento \\ YSZ Ytria Stabilized Zirconia
}

\section{INTRODUCTION}

The technology of fuel cells arouses interest both in the general population and in the technicalscientific and business community. Due to the constant concern for a pollution generated by ICE automobiles, fuel cells arises as a promising alternative for propulsion mechanism in automobiles, since they carry with them the advantage of not emitting pollutants, contributing to the environment preservation.

In this sense, the researches with fuel cells (FC's) reactivated. Though the studies on FC's are ancient, since they have been recognized by science for about 150 years, the academic community and the companies, intensified the researches on this subject because this technology is pointed out with one of the main energy solutions. "It's just a matter of time for this technology to be a part of people's lives, just as it was with personal computers [...]" (Vargas, et al., 2006).

\section{PROSPECTS}

The large number of ICE automobiles on the market has contributed to several environmental 
issues since the main fuel used in motor vehicles are derived from oil. However, the tendency is for oil to lose its prevalence, being replaced progressively by other alternative sources and contrary to the forecasts made in the last century, its end will be due to economic dynamics and environmental laws, and not exclusively by the exhaustion of reserves.

In this way, the industry has work to reduce emissions and increase the efficiency of vehicles. While several mechanical, control and calibration strategies, such as downsizing and direct injection, have been important mechanisms for reducing pollutant emissions and fuel consumption, emissions levels remain high and are considered unsustainable for the future. Alternatively, electric vehicles (EV), hybrid electric vehicles (HEV) and fuel cell electric vehicles (FCEV) have been proposed and developed, gaining market share.

Several studies reaffirm the theory that internal combustion engines have the right time to be replaced by other forms of propulsion. One of them, carried out by the McKinsey \& Company institution on its publication "Boost! Transforming the powertrain value chain - a portfolio challenge", 2011, in its intermediate scenario, projects to 2030 the year that the ICE loses its reign for pure electric vehicles (HEV) and by 2050, the year in which it will practically not be available in the market. The FCEV appears with a notable market percentage in the intermediate and promising scenarios. The results found by the McKinsey \& Company institution were divided into 3 scenarios, represented on Fig. 1 (McKinsey \& Company, 2011).

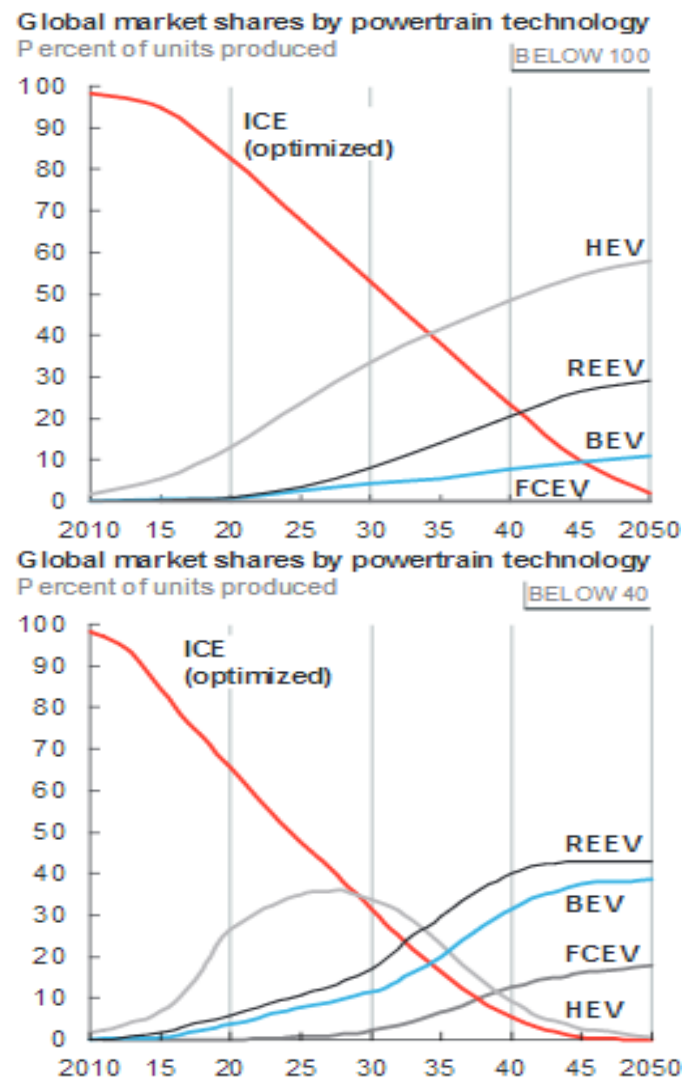

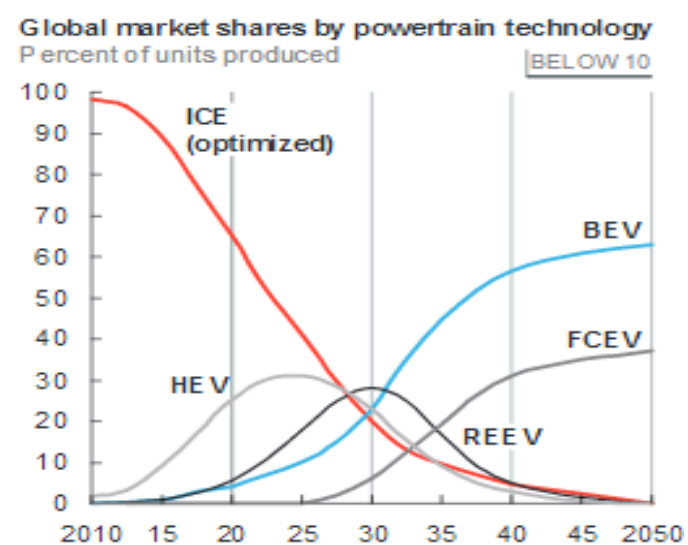

Figure 1. Market outlook for car propulsion: conservative, intermediate and promising scenario, respectively.

\section{FUEL CELL FEATURES}

Fuel cell is a galvanic cell with continuous operation that transforms chemical energy into electrical energy.

The conversion takes place through two reactions, which occurs in the anode and the cathode, separated by an electrolyte. The oxidation of the fuel occurs in the anode, while the reduction of an oxidant occurs in the cathode.

Generally speaking, the fundamental components of this system, are a stack of FC, fuel, oxidant, energy storage and a power conditioner, which will power the load. Fig. 2 shows a block diagram of the general operation of a fuel cell system.

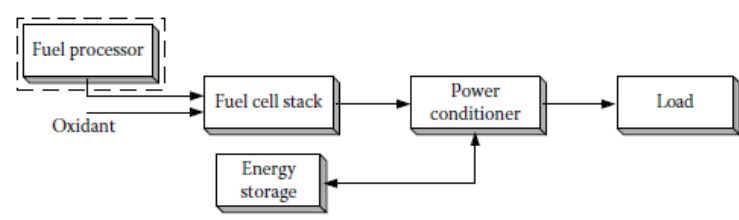

Figure 2. FC System (GOU, Na and Diong, 2010).

PEMFC were developed by GE and Siemens from the 1960s and represent the most viable cell type to be implemented in automotive vehicles especially because of its temperature range operation and power density.

Its structure consists basically of two graphite electrodes with platinum catalyst, Nafion membrane as electrolyte, Hydrogen gas as fuel and Oxygen or air as oxidant.

The potential difference between the anode and the cathode accelerated by the catalytic effect of platinum promotes the anodic, cathodic and global reactions. The electrons are driven by an external circuit from the anode to the cathode and feed the charge, the protons pass through the electrolyte that must be humidified to maximize the conduction of positive charges. Figure 3 illustrates the operation of a PEMFC. 


$$
\begin{gathered}
\text { Anode }: 2 \mathrm{H}_{2(\mathrm{~g})} \rightarrow 4 \mathrm{H}^{+}+4 \mathrm{e}^{-} \\
\text {Cathode }: \mathrm{O}_{2(\mathrm{~g})}+4 \mathrm{H}^{+}+4 \mathrm{e}^{-} \rightarrow 2 \mathrm{H}_{2} \mathrm{O}_{(\mathrm{l})} \\
\text { Global }: 2 \mathrm{H}_{2(\mathrm{~g})}+\mathrm{O}_{2(\mathrm{~g})} \rightarrow 2 \mathrm{H}_{2} \mathrm{O}_{(\mathrm{l})}
\end{gathered}
$$

The equations 1, 2 and 3 shows respectively, the anodic, cathodic and global reactions.

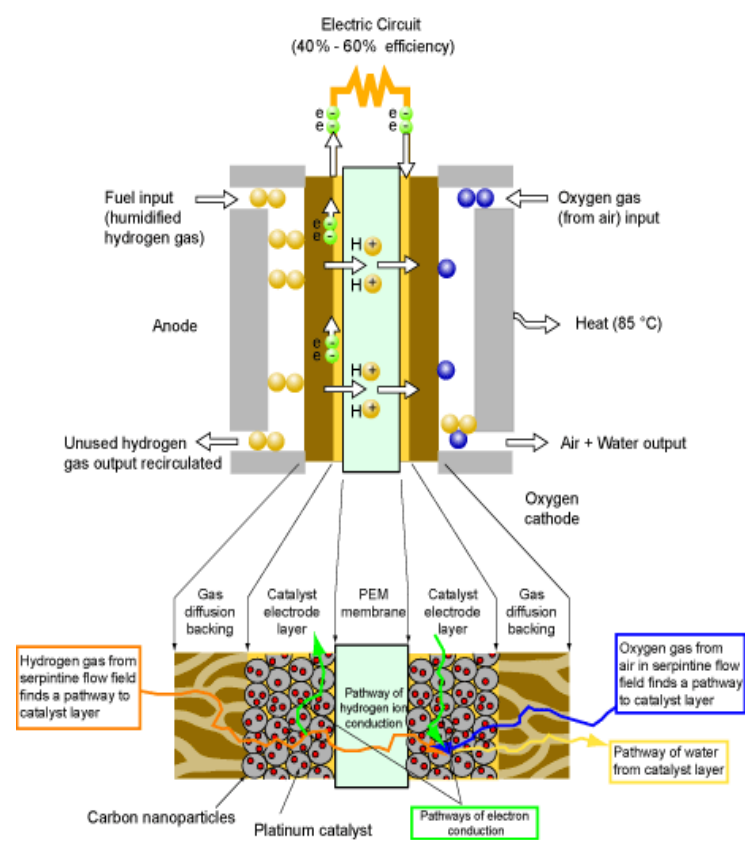

Figure 3. Schematic of a PEMFC (National Institute of Standards and Technology, 2006).

Figure 3 can be found on http://physics.nist.gov/MajResFac/NIF/pemFuelCells .html website and were accessed in April 2017.

In this way, the inputs of a PEMC are hydrogen and oxygen, while the outputs are water, heat and electric power.

$$
\mathrm{P}=\mathrm{i} \cdot \mathrm{E}
$$

The electric power in one cell is given by Eq. 4, where $\mathrm{i}$ is the electrical current and $\mathrm{E}$ the cell voltage.

It is worth mentioning that power density depends on several factors, such as the unit cell area, number of cells, fuel and oxidant concentrations and operating temperature. These impacts will be discussed later.

The benefits of using a fuel cell in an automobile are diverse, reaching mainly tree spheres: environmental, social and economic.

The main environmental advantages are:

- Reduction of dependence on oil products for energy production;

- Zero emission of pollutants; or a significant reduction in the emission of pollutants when hydrogen is produced from fossil sources;
- Greater efficiency in power generation;

- Decreased use of conventional batteries, which are harmful to the environment when disposed of in landfills.

The social advantages are:

- Secure technology;

- Reduction of noise pollution, since fuel cells have no moving parts and operate silently;

- Reduction of particulate matter in the atmosphere, such as smoke ash, which impairs respiratory health.

Finally, the economic advantages:

- Economic growth and job creation.

Regarding the disadvantages, fuel cells are still an expensive technology, making it impossible to implement them in short-term. The great volume and weight of the equipment also presents a challenge, since the tendency is directed towards cars lighter and compact. It can be said that these challenges have been overcome, as technology and research advances, so that in a few years the replacement of internal combustion engines is economically and functionally viable (Braga, el al., 2009).

Another relevant factor to be highlighted is the need for a solid Hydrogen production and distribution infrastructure. Several are the sources of production of this fuel, however, much remains to be done to ensure safe and accessible distribution. The production of Hydrogen from the reform of other fuels is strategic for Brazil when it comes to ethanol. The researchers also considered the production of the fuel by the electrolysis of water, either by photovoltaic process or by the use of thermal energy generated in nuclear reactors (Janólio, et al., 2002).

While the disadvantages are punctual and have been overcome, the advantages are many, besides being in synergy with the new needs and demands of society.

\section{MATHEMATICAL CALCULATIONS}

For a better understanding of the functioning of fuel cells, some parameters can be determined from theoretical mathematical calculations. For this, calculations considering a standard behavior (temperature of $25^{\circ} \mathrm{C}$ and pressure of $1 \mathrm{~atm}$ ) were performed. In addition, calculations for the temperature $80^{\circ} \mathrm{C}$, operating temperature of a PEMFC, were also performed.

Since fuel cells are a galvanic cell, voltage is a very important variable. This variable is directly related to electric current and Gibbs free energy. The voltage generated, $\mathrm{E}$, in the galvanic cells is linked to the available free energy, $\Delta \mathrm{G}$, and to the number in moles of electrons per moles of formed products, n, in addition to the Faraday constant, F.

$$
\mathrm{E}=\frac{\Delta \mathrm{G}}{-\mathrm{n} \cdot \mathrm{F}}
$$


The Gibbs free energy can still be understood as the energy from which the process disposes to perform useful work at constant temperature and pressure. The Gibbs free energy represents the useful work performed, the enthalpy change $(\Delta \mathrm{h})$ represents the total energy released and $\mathrm{T} \Delta \mathrm{s}$ represents the irreversibility, energy rejected as heat.

$$
\Delta \mathrm{G}=\Delta \mathrm{h}-\mathrm{T} \cdot \Delta \mathrm{s}
$$

The relation between the free energy of Gibbs and the operating temperature is given by linearizing the equation of $\Delta \mathrm{G}$ under standard conditions and assuming that the variation of $\Delta \mathrm{h}$ with temperature is zero. Such a consideration was made according to the study by Collen Spiegel, presented in the book "PEMFC Fuel Cell Modeling and Simulation Using MATLAB” (Spiegel, 2008).

$$
\begin{aligned}
& \frac{\partial \Delta G}{\partial T}=\frac{\partial \Delta h}{\partial T}-\left(\frac{\partial T}{\partial T} \cdot \Delta s+\frac{\partial \Delta s}{\partial T} \cdot T\right) \\
& \therefore \partial \Delta G=-\Delta s \cdot(T-25)
\end{aligned}
$$

Thus, analogously to the considerations made previously, it is also possible to correlate the potential of the cell to the variation of temperature from a linearization.

$$
\begin{aligned}
& \frac{\partial E}{\partial T}=-\frac{1}{n \cdot F}\left[\frac{\partial \Delta h}{\partial T}-\left(\frac{\partial T}{\partial T} \cdot \Delta s+\frac{\partial \Delta s}{\partial T} \cdot T\right)\right] \\
& \therefore \Delta E=\frac{\Delta s}{n \cdot F} \cdot(T-25)
\end{aligned}
$$

In addition to temperature, other factors influence the value of the voltage. From the Nernst equation, for example, it is possible to evaluate the influence of the concentration of the reactants. $\mathrm{E}^{\mathrm{o}}$ is the standard voltage, $\mathrm{R}$ is the universal gas constant, $\mathrm{T}$ is the operating temperature and $\mathrm{k}$ is the equilibrium constant of the reaction.

$$
E=E^{0}-\frac{R \cdot T}{n \cdot F} \cdot \ln (k) \therefore k=\frac{[C]^{c}[D]^{d}}{[A]^{a}[B]^{b}}
$$

Eq. 9 represents the Nernst equation.

Efficiency is the measure that represents how much a system manages to produce from working from a supplied energy. The study of efficiency is very important in ICE vehicles, since the higher the efficiency value, the larger is the input energy that is converted into work. It is known that a combustion engine can convert up to $35 \%$ of the energy present in the fuel into work, dissipating the rest in the form of vibration, noise, heat, etc. and a PEMFC fuel cell has a efficiency between 30 and $90 \%$ greater than conventional petrol-fueled internal combustion engines (Mekhilef, et al., 2011).
Since the work produced by a fuel cell is electrical work, represented by the value of $\Delta \mathrm{G}$, and the total energy is the enthalpy change $\Delta H$, the thermodynamic efficiency in the galvanic cells is given equation below:

$$
\eta=\frac{W}{Q} \therefore \eta_{t}=\frac{\Delta G}{\Delta H}
$$

From the equations and considerations described, the theoretical calculations were performed and placed in the Tab. 1, Tab. 2 and Tab. 3 below:

Table 1. Theoretical calculation results for standard conditions, $\mathrm{T}=25^{\circ} \mathrm{C}$ and $\mathrm{P}=1 \mathrm{~atm}$.

\begin{tabular}{ccc}
\hline & Equation & Result \\
\hline I & $\Delta \mathrm{G}^{0}=\Delta \mathrm{H}^{0}-\mathrm{T} \cdot \Delta \mathrm{s}^{0}$ & $\Delta G^{0}=-237,177.50 \frac{\mathrm{J}}{\mathrm{mol}}$ \\
\hline II & $\mathrm{E}=\frac{\Delta \mathrm{G}}{-\mathrm{n} \cdot \mathrm{F}}$ & $E^{0}=1.229 \mathrm{~V}$ \\
\hline II & $\eta_{\max }{ }^{0}=\frac{\Delta \mathrm{G}^{0}}{\Delta \mathrm{H}}$ & $\eta_{\max }{ }^{0}=82.98 \%$ \\
\hline
\end{tabular}

Table 2. Theoretical calculation results for $\mathrm{T}=80^{\circ} \mathrm{C}$ and $\mathrm{P}=1 \mathrm{~atm}$.

\begin{tabular}{ccc}
\hline & Equation & Result \\
\hline IV & $\begin{array}{c}\Delta \mathrm{G}=\Delta \mathrm{h}-\mathrm{T} \cdot \Delta \mathrm{s} \\
\partial \mathrm{G}=-\Delta s \cdot(T-25)\end{array}$ & $\Delta G=-228,198.75 \frac{\mathrm{J}}{\mathrm{mol}}$ \\
\hline & $\mathrm{E}=\frac{\Delta \mathrm{G}}{-\mathrm{n} \cdot \mathrm{F}}$ & $\mathrm{E}=1.183 \mathrm{~V}$ \\
V & $\Delta \mathrm{E}=\frac{\Delta \mathrm{s}}{\mathrm{n} \cdot \mathrm{F}} \cdot(\mathrm{T}-25)$ & \\
VI & $\eta=\frac{\Delta \mathrm{G}}{\Delta \mathrm{H}}$ & $\eta_{80, \max }=79.84 \%$ \\
\hline
\end{tabular}

Table 3. Theoretical calculation results for $\mathrm{T}=25^{\circ} \mathrm{C}$, $\mathrm{P}=1 \mathrm{~atm}$ and open cathode: [O2] = 21\%.

\begin{tabular}{cc}
\hline Equation & Result \\
VII $\quad \mathrm{E}=\mathrm{E}^{0}-\frac{\mathrm{R} \cdot \mathrm{T}}{\mathrm{n} \cdot \mathrm{F}} \cdot \ln (\mathrm{k})$ & $E=1.219 \mathrm{~V}$
\end{tabular}

As can be seen in items I and IV, Gibbs free energy is higher, in modulus, at room temperature. The negative sign indicates only that the process is exothermic, that is, it occurs spontaneously. Thus, in this temperature range, the lower the temperature, the greater is the spontaneity of the reaction.

Since the Gibbs free energy decreases with increasing temperature, the same behavior can be observed for the voltage, evidenced from items II and $\mathrm{V}$. At room temperature, therefore, the same cell generates more voltage than in high temperatures. 
For the previous calculations, a concentration of $100 \%$ of oxygen gas in the cathode was considered. If the cell operates with open cathode, this concentration will drop to $21 \%$, since only about $1 / 5$ of the gases present in the air is Oxygen. Given this, comparing items II and VII, it is possible to conclude that the voltage falls when the concentration of the reactants decreases.

Finally, it is possible to say that, according to items III and VI, the efficiency of a fuel cell drops with the increase in temperature, as well as the observed behavior for electric potential and Gibbs free energy.

\section{COMPUTATION PROCEDURE}

In addition to the calculations, a computational procedure also supports the validation of the study of fuel cells, especially in comparison with internal combustion engines. ADVISOR software is designed for fast performance analysis of conventional, hybrid and electric vehicles, meeting project needs. This software was developed as an analysis tool, not originally as a detailed design tool. It is an iterative evaluation tool that simulates the operation of a vehicle, using mainly empirical models based on measurements made in laboratories.

For the feasibility study between the fuel cell driven propellant and the internal combustion engine, a simulation pattern was followed in order to obtain an appropriate form of comparison. To make these technologies comparable, some considerations have been made: both vehicles are small utility cars, which perform similar maximum powers of approximately $50 \mathrm{~kW}$. Thus, all other components, such as transmission, axle and wheels, have been set equal for both vehicles. It is important to note, however, that the mass of the vehicle moved to the FC is 400 $\mathrm{kg}$ higher than the mass of the ICE, solely due to the difference in weight between the propeller sets.

It was decided to make several simulations of cycles with constant velocity and to analyze the results obtained in steady state. In this way, several simulations were performed with constant velocity, from 40 to $120 \mathrm{~km} / \mathrm{h}$, for FC and ICE. The results were plotted as a function of vehicle speed and nonengine speed.

\section{RESULTS AND DISCUSSION}

\section{Efficiency analysis}

It is important to note that for a fair comparison between technologies, the efficiency of the internal combustion engine should be compared to the efficiency found at the output of the electric motor. That is, in the case of FC, the efficiencies of the fuel cell and the electric motor are taken into account.

Figure 4 shows the results of these efficiencies, besides showing the difference between the values found. Figure 5 singles out the efficiencies of the fuel cell and the electric motor.

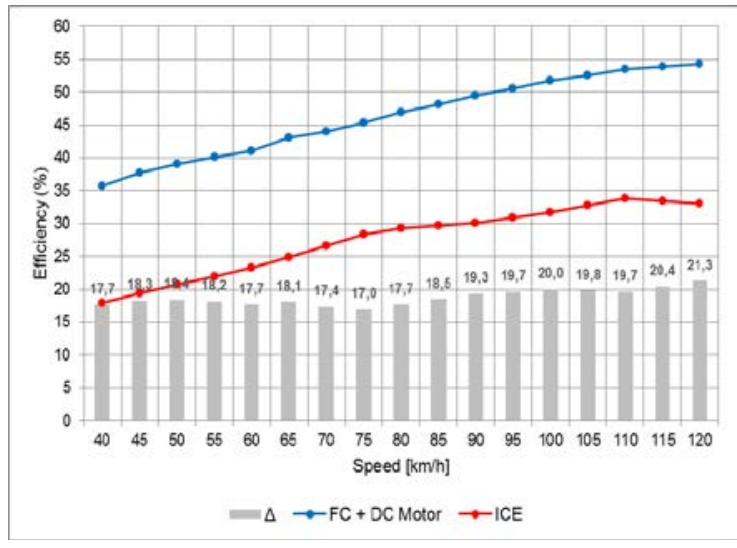

Figure 4. System Efficiency.

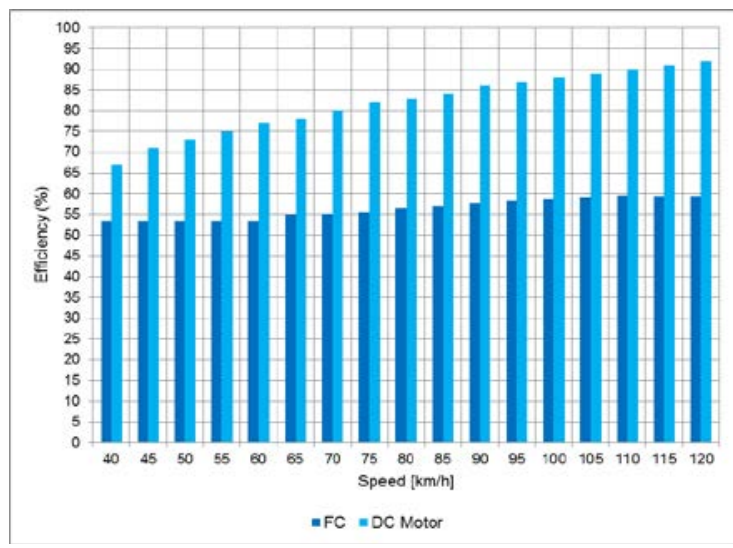

Figure 5. Fuel Cell Efficiency.

According to the simulations, it can be seen that the FC driven propulsion system has significantly higher efficiency values, reaching $54.32 \%$ at the maximum simulation speed while the ICE reaches $33.84 \%$ at its optimum operating point, which represents a $60 \%$ lower value than in the case of FC.

Regarding the exclusive efficiency of the fuel cell, even if the maximum value reached of $59.53 \%$ is about $34 \%$ below the value found in the theoretical procedures, such value has synergy with the current state of the art presented. The discrepancy of the value found in the simulations for the calculated is due to numerous sources of irreversibilities present in a fuel cell stack that were not considered in the theoretical procedures, and their studies are not part of the scope of this article.

\section{Performance analysis}

Since both vehicles develop the same speeds, it can be said that both propulsion systems achieve the required performance levels. The way the systems achieve such performance is determined by the torque and power curves highlighted in Figures 6 and Figure 7. 
Although the software already provides the maximum torque curve of the vehicle, which represents the maximum torque it can achieve for each rotation, the analysis was made of the operating points of each simulation, as this would find the instantaneous value of torque for each vehicle speed.

$$
\mathrm{P}=2 \cdot \Pi \cdot \mathrm{n} \cdot \mathrm{T}
$$

Eq. 11 shows how the power curves are calculated.

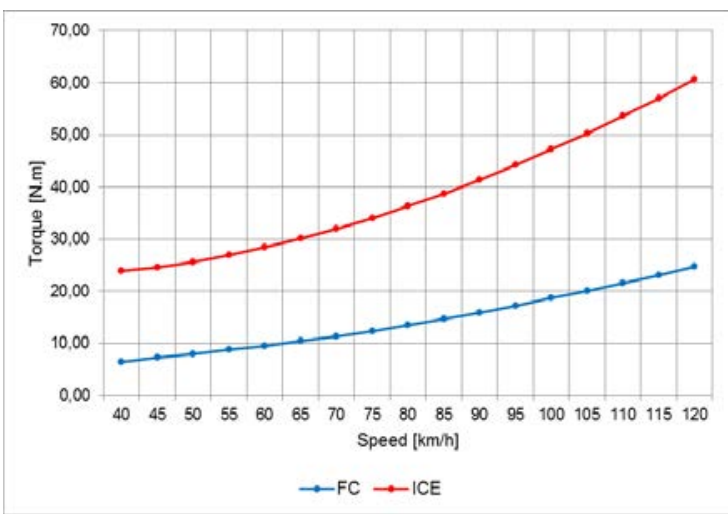

Figure 6. Torque curve.

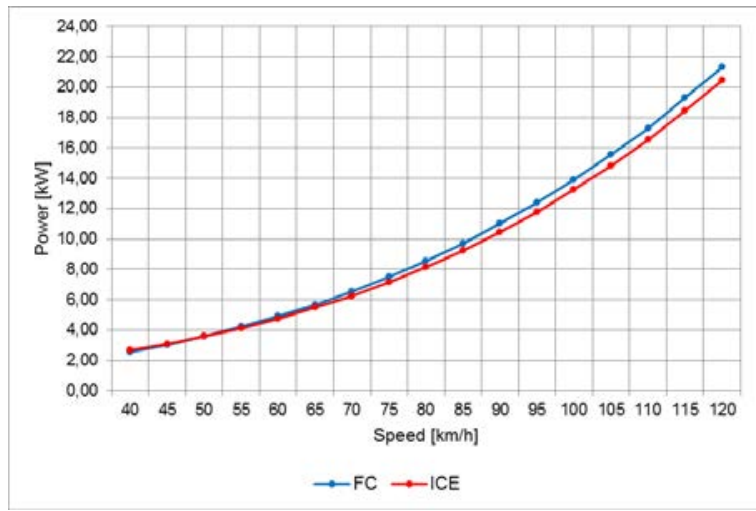

Figure 7. Power curve.

By means of the obtained results, it can be concluded that the torque in both propulsion systems increases proportionally with the vehicle speed, since larger values of speed require a greater force of the motor. In addition, the torque values of the internal combustion engine were significantly higher than the fuel cell values.

However, when analyzing the power curve, it can be seen that both vehicles had very similar results, even with ICE having higher torque values. This is due to the fact that the rotation found in the AC motor is greater than the rotation found in the ICE, for the same vehicle speed.

\section{Emissions analysis}

One of the most important aspects in terms of comparison between the two vehicular technologies is the emission of pollutant gases to the atmosphere.
According to statistics from the International Energy Agency (IEA), $23 \%$ of global $\mathrm{CO}_{2}$ emissions from fossil fuel combustion come from the transport sector.

Using the same simulation method, Figure 8 was constructed to show the emission of hydrocarbons, carbon monoxide and nitrogen oxides in grams per second for each speed range and for each form of propulsion. Figure 9 highlights the amount in grams of pollutants emitted in a 5-minute cycle.

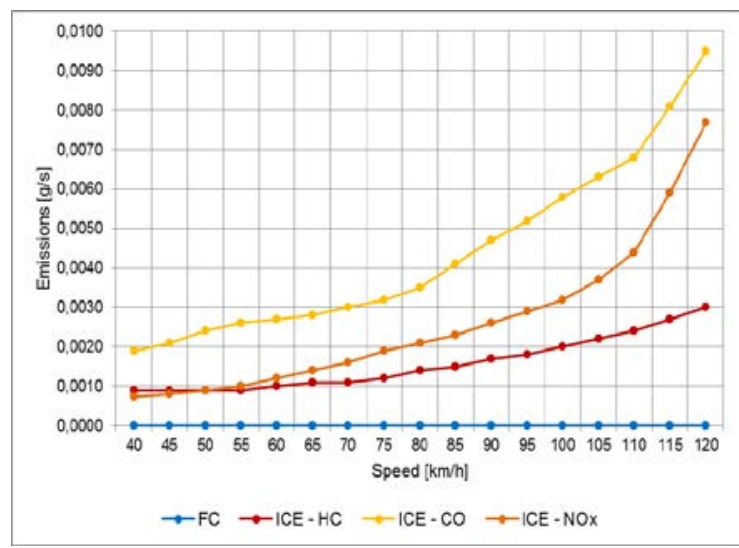

Figure 8. Pollutant Emissions in g/s.

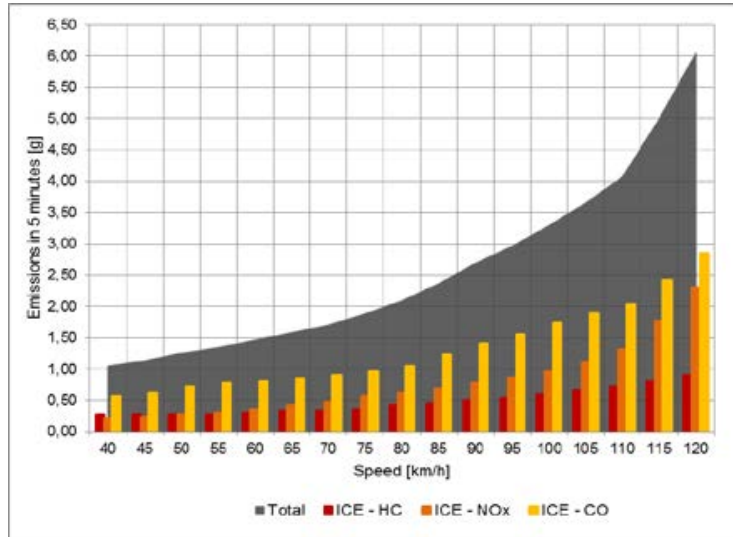

Figure 9. Pollutant Emissions in g in a 5-min cycle.

As expected, the fuel cell powered vehicle did not emit any pollutants at all simulated speeds. On the other hand, the combustion engine vehicle issued, among others, the three pollutants highlighted in Figure 9. It reached more than 6 grams of pollutants in $5 \mathrm{~min}$ at a speed of $120 \mathrm{~km} / \mathrm{h}$.

\section{Consumption analysis}

In order to make a comparison between the fuel consumption between two vehicles that use substances with very distinct properties, it is necessary to consider some aspects previously. It is known that gasoline is a fuel that when injected into the engine is in its liquid form and has a density of approximately $0.72 \mathrm{~g} / \mathrm{cm}^{3}$ under normal conditions of 
pressure and temperature. On the other hand, hydrogen, as naturally occurring in the gaseous state, has a density well below gasoline, of approximately $0.00009 \mathrm{~g} / \mathrm{cm}^{3}$ under normal conditions of pressure and temperature. A 75-liter tank with this gas would move an average car for about 150 meters. That way, to increase the amount of hydrogen in a tank, it needs to be stored under high pressure, which can reach 700 bar in a utility vehicle.

Figure 10 represents the consumption in $\mathrm{km} / \mathrm{L}$ and Figure 11 in $\mathrm{km} / \mathrm{kg}$ for the internal combustion engine and for the fuel cell, considering that the software already takes into account pressurized hydrogen in the case of the fuel cell.

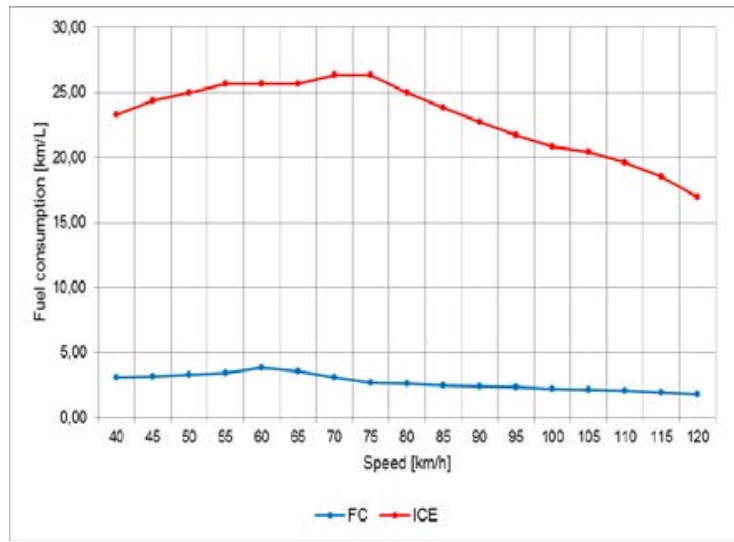

Figure 10. Fuel consumption (km/L).

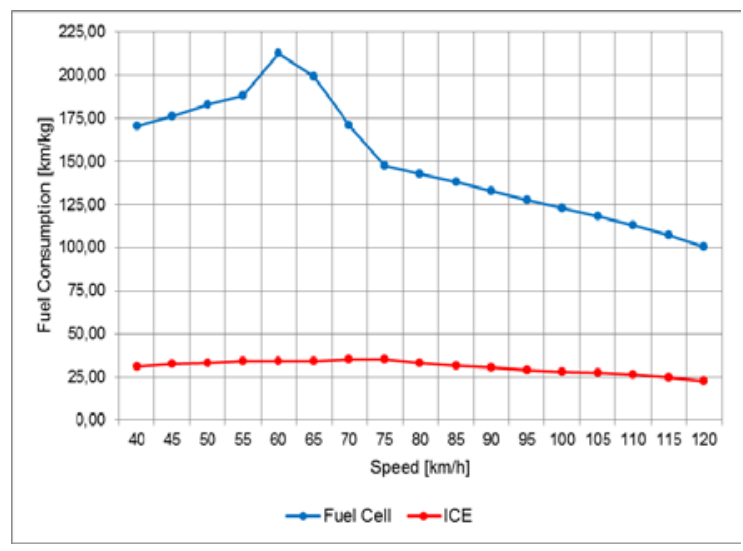

Figure 11. Fuel consumption (km/kg).

According to the simulations, it can be seen that the propulsion system moved to ICE has significantly lower volumetric consumption values, reaching 26.32 $\mathrm{km} / \mathrm{L}$ between speeds of 70 to $75 \mathrm{~km} / \mathrm{h}$, while the FC reaches only $3.83 \mathrm{~km} / \mathrm{L}$ at its optimum point of operation. Comparing the values of mass consumption to FC reaches incredible $212.86 \mathrm{~km} / \mathrm{kg}$ of hydrogen, which represents a value of mass consumption 6 times smaller than the ICE mass consumption, which reaches only $35.13 \mathrm{~km} / \mathrm{kg}$.

The cycles with constant velocities used, however, present an unusual condition and very ideal for analysis of fuel consumption. Therefore, in addition to these simulations, two more simulations were made with urban and road cycles, shown in Figures 12 and 13, respectively.

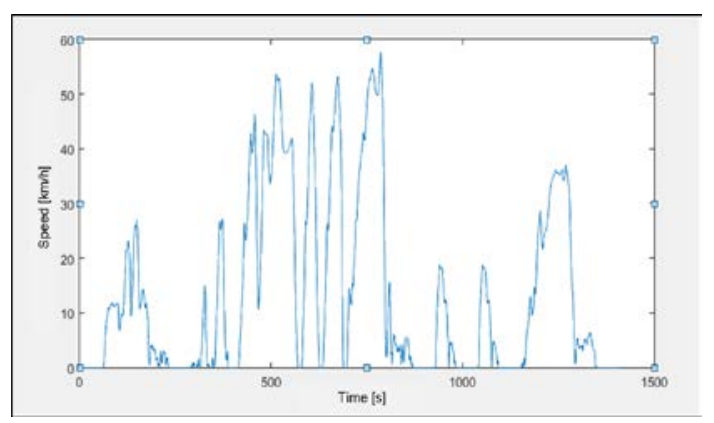

Figure 12. Urban cycle.

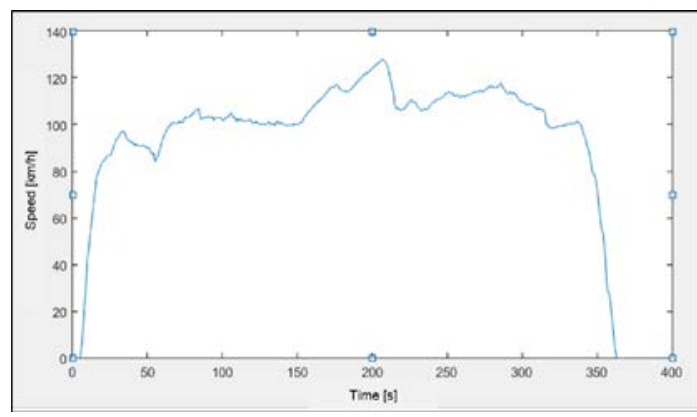

Figure 13. Road cycle.

The urban cycle has an average speed of 13.5 $\mathrm{km} / \mathrm{h}$ and has a total distance of $5.32 \mathrm{~km}$, reaching a top speed of $58 \mathrm{~km} / \mathrm{h}$. The cycle of the road, has a total distance of $10.04 \mathrm{~km}$, average speed of $98 \mathrm{~km} / \mathrm{h}$ and maximum speed of $129 \mathrm{~km} / \mathrm{h}$. The consumption found for the urban and road cycles are presented, respectively, in the Figures 14 and 15 below:

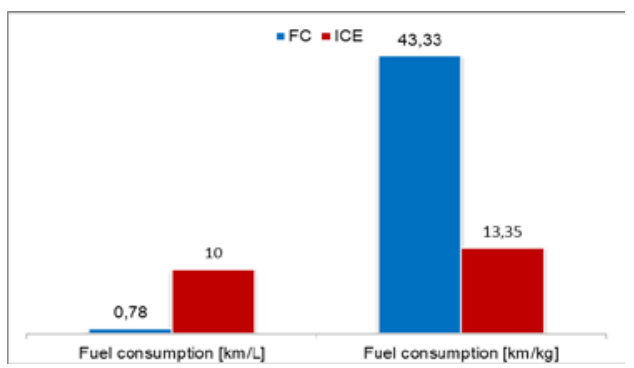

Figure 14. Fuel consumption of the urban cycle.

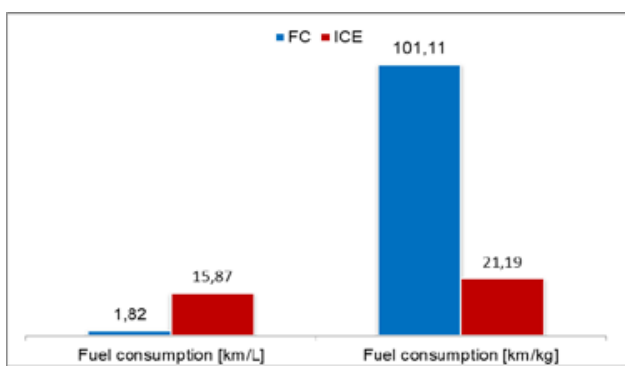

Figure 15. Fuel consumption of the road cycle. 
It can be observed, as expected, that consumption on the road is lower than urban consumption. Both vehicles had these results. But it becomes clear that the mass consumption for the fuel cell is significantly lower than for ICE in both simulations. Thus, for common uses of vehicles, it can be stated that for a same mass of fuel, the FC guarantees a greater autonomy than the ICE.

\section{Economic analysis}

For the economic analysis, the estimated data of the National Renewable Energy Laboratory (NREL) in the study of energy demand in transportation for the prices of hydrogen and gasoline were used. Since the data estimate the price of these fuels up to 2025, a continuation of this projection was made, following the trend, up to the year 2040, as shown in Figure 16.

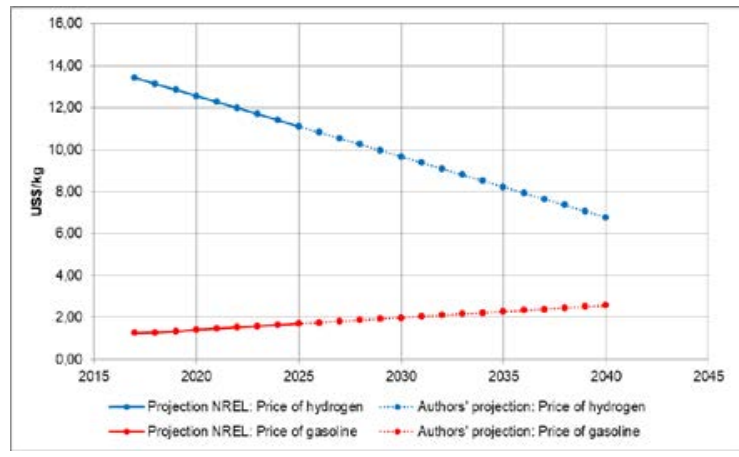

Figure 16. Projection of fuel prices until the year 2040.

From these values, the cost for the urban and road cycles already mentioned in this article was calculated annually until 2040. These results, respectively, are shown in Figures 17 and 18:

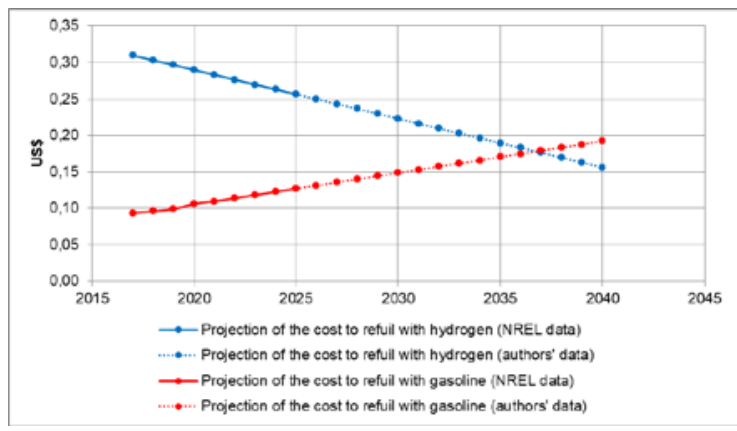

Figure 17. Projection of cost for the urban cycle.

Thus, based on the estimates, which in turn are even conservative, it is observed that in the future, it will be more economically feasible to replace internal combustion engines with fuel cells. For the cycle urban cycle, it becomes cheaper to supply with hydrogen from the year 2037. In the road cycle, in turn, the ICE becomes impracticable from the year 2030 .

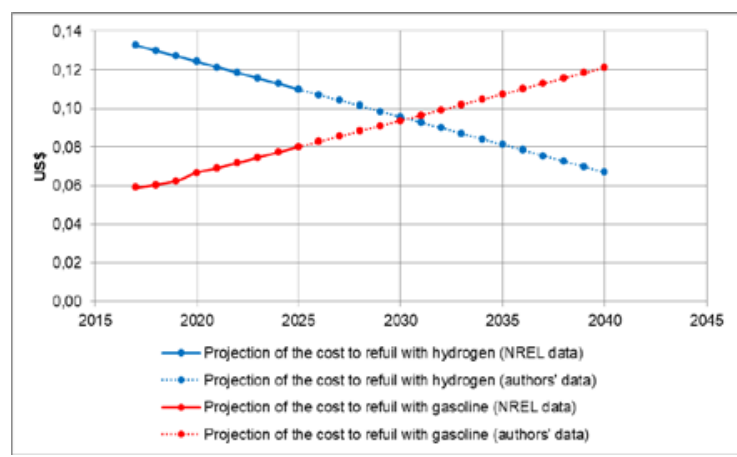

Figure 18. Projection of cost for the road cycle.

Although hydrogen is still more expensive, at USS $\$ / \mathrm{kg}$, than gasoline, fueling this fuel will be cheaper due to much higher gasoline consumption.

\section{CONCLUSIONS}

Through the study of the main characteristics of fuel cells, especially in PEMFC, it was possible to understand the operation and how some variables affect the performance of this promising technology.

As analysis of the propulsion systems efficiency, the maximum value of $54.32 \%$ for the FC system was obtained, while the internal combustion engine presented a value of $33.84 \%$. Regarding the performance, it was verified that, although ICE had higher torque values than the fc propulsion system, both technologies met the demands of work requested.

For fuel consumption, two situations were analyzed: consumption in $\mathrm{km} / \mathrm{L}$ and $\mathrm{km} / \mathrm{kg}$, due to the large difference in fuel density. The ICE had a maximum consumption of $26.32 \mathrm{~km} / \mathrm{L}$ or 35.13 $\mathrm{km} / \mathrm{kg}$ while a FC reached a value of $3.83 \mathrm{~km} / \mathrm{L}$ or $212.86 \mathrm{~km} / \mathrm{kg}$. That is, when it is calculated as a function of mass, a FC is more advantageous, with a consumption 6 times lower than ICE.

As expected, the fuel cell powered vehicle did not emit any pollutants at all simulated speeds. On the other hand, the combustion engine vehicle issued, among others, the three pollutants highlighted in Figure 9. It reached more than 6 grams of pollutants in $5 \mathrm{~min}$ at a speed of $120 \mathrm{~km} / \mathrm{h}$.

Another encouraging result found, was the level of emissions released by both propulsion systems. While ICE emits more than 6 grams of harmful gases into the environment in a 5-minute cycle at high speed, the FC system has zero level emissions in any drive cycle, meeting current and future environmental demands.

Finally, considering only the fuelling cost, an economic analysis shows us that today, the price for FCEV is higher than the conventional vehicles, however, conservative scenarios predict that from the year 2037, the fuelling for FCEV will be more economically viable than for ICE vehicles.

Therefore, PEMFC is an efficient and clean 
technology and comes as a reality to be part of the propulsion systems that will come to replace, in the medium term, the ICE in conventional vehicular applications.

\section{REFERENCES}

Braga, L. B., de Souza, A. C. C., Silveira, J. L., and Antunes, J. S., 2009, Análise Técnica e Econômica para o Uso de Célula a Combustível em Ônibus, Revista Ciências Exatas, Vol. 15, No.1, pp. 1-10. (in Portuguese)

Ett, G., Janolio, G., Ett, V., Ebesui, A. M., Vulcano, G., and Junqueira, M. S. D., 2002, Geração de Energia Elétrica Distribuída a Partir de Célula a Combustível, in: $4^{\circ}$. Encontro de Energia no Meio Rural, Campinas, SP. (in Portuguese)

Gou, B., and Diong, B., 2010, Fuel Cells: Modeling, Control, and Applications, CRC Press.

Mark, A. D., and Timothy, E. L., 2010, Lifetime Cost of Battery, Fuel-Cell and Plug-in Hybrid Electric Vehicles, University of California, Davis, USA.

McKinsey \& Company, 2011, Boost! Transforming the Powertrain Value Chain, Portfolio Challenge.

Mekhilef, S., Saidur, R., and Safari, A., 2011, Comparative Study of Different Fuel Cell Technologies, Renewable and Sustainable Energy Reviews, Vol. 16, pp. 981-989.

Melaina, M., and Penev, M., 2013, Hydrogen Station Cost Estimates: Comparing Hydrogen Station Cost Calculator Results with other Recent Estimates, National Renewable Energy Laboratory.

Spiegel, C., 2008, PEM Fuel Cell Modeling and Simulation Using MATLAB, Elsevier, USA.

Vargas, R. A., Chiba, R., Franco, E. G., and Seo, E. S. M., 2006, Uma Visão da Tecnologia de Células a Combustível, Renewable Energy Sources, Instituto de Pesquisas Energéticas e Nucleares, IPEN. (in Portuguese) 